\title{
Study of Physico- chemical Characteristics of Water in River Mandakini
}

\author{
Dr Arvind Prasad Dwivedi \\ Lecturer, Department of chemistry, Govt. Sanjya Gandhi Smrati Auto P.G. College Sidhi M.P., India
}

*Corresponding Author: Dr. Arvind Prasad Dwivedi, Lecturer, Department of chemistry, Govt. Sanjya Gandhi Smrati Auto P.G. College Sidhi M.P., India

\begin{abstract}
The physico-chemical parameters of water samples collected from river mandakini at various locations of chitrakoot District were assess. Physico-chemical parameters like, Temperature, pH, Alkalinity, TDS, Chloride, Total Hardness, Sulphate and Phosphate was determined. The river mandakini originates near village kalhura in the majhgawan block, district Satna of Madhya Pradesh at latitude $24^{0} 52^{\prime} \mathrm{N}$ and longitude $80^{\circ} 41^{\prime}$ 'E. The results were compared with standards prescribed by WHO (1984). Temperature, $p H$, Chloride, Sulphate and phosphates of all the samples were found below the permissible limit set by WHO. It is concluded that the water of river is not highly polluted but there is an indicating of increasing pollutant due to anthropogenic activities. Proper monitoring is needed to avoid anthropogenic contamination.
\end{abstract}

Keywords: Physico-chemical Parameters, River water, River Mandakini, Chitrakoot District

\section{INTRODUCTION}

The river mandakini originates near village kalhura in the majhgawan block, district Satna of Madhya Pradesh at latitude $24^{\circ} 52^{\prime} \mathrm{N}$ and longitude $80^{\circ} 41^{\prime} \mathrm{E}$. The river flows generally in a south to north direction, through in the first and last reaches a west to east trend is also significant. The river flows in Madhya Pradesh for about $25 \mathrm{~km}$, then makes a border of district Satna (Madhya Pradesh) and district chitrakoot (Utter Pradesh) for next $25 \mathrm{~km}$ and again enters in Madhya Pradesh just downstream of Sati Anusuiya, After flowing through about $15 \mathrm{~km}$ more in M.P., it croses into Utter Pradesh near Ramghat in chitrakoot area and later flows only in Utter Pradesh finally it joins river Yamuna near Rajapur ${ }^{[1]}$.

India is a country having land forms and rivers. There are 14 major rivers in India. The rivers of India play an important role in the lives of the Indian people. The river systems provide irrigation, potable water, electricity and the livelihoods for a large number of people all over the country. ${ }^{[2-5]}$

Water is the most important in shaping the land and regulating the climate. It is one of the most important compounds that profoundly influence life. The quality of water usually described according to its physical, chemical, characteristics. Rapid industrialization and indiscriminate use of chemical fertilizers and pesticides in agriculture are causing heavy and varied pollution in aquatic environment leading to deterioration of water quality and depletion of aquatic biota. Due to use of contaminated water, human population suffers from water born diseases. It is therefore to check the water quality at regular interval of time ${ }^{[6]}$. The present study is an attempt to make an assessment of the change in the quality of water of river mandakini by the addition of urban waste of chitrakoot city. An attempt has been made to study the extent of change in the quality of water in comparison to water quality standards of world health organization, (WHO, 1984).

\section{Materials AND Methods}

Physico-chemical characteristics of water in river Mandakini is conducted during month of April 2013. Location of the sampling station were given below the table-1.Sampling was done accordance with Grab sampling method in polyethylene bottles of one liter capacity to avoided leaching of metals and interaction with the surface wall of the container, bottles were first cleaned with detergent and then socked in 1:1 $\mathrm{HNO}_{3}$ for 24 hours. Finally the bottles were cleaned and rinsed with distilled water [7]. During sampling bottles were rinsed two to three times with the samples to be examined before filling with it. Samples were collected by immersing the rinsed bottles in river waters. All the samples were labeled showing the source date and time of collection. The samples were labeled, showing the 
source date and time of collection. The samples were refrigerated at $4{ }^{0} \mathrm{C}$ in the laboratory ${ }^{[8-11]}$. The Procedures followed to analyze the Heavy metal concentration were from Standard Methods (APHA 1984). ${ }^{7}$

\section{RESULT AND DISCUSSION}

The water samples were analysed some parameter like Temperature, $\mathrm{pH}$, Alkalinity, Chloride, TDS, TH, Sulphate, and Phosphate. Analysed all the results are presented in Table-1 and drinking water standard values are presented in Table-2 Graphical representations of the data were shown in fig-1-8.

The present research works identify Physico-chemical characteristics of water of River Mandakini in Chitrakoot Rigion. The results of water quality of River Mandakini in Chitrakoot are given below.

\subsection{Temperature}

Temperature is an important factor, which regulates the geo chemical activities in the aquatic environment. Temperature of Mandakini river water range $26^{\circ} \mathrm{C}$ from to $33^{\circ} \mathrm{C}$.The maximum temperature was recorded $33^{\circ} \mathrm{C}$ at sampling location $\mathrm{M}_{4}$ and the minimum temperature is $26^{\circ} \mathrm{C}$ in Chitrakoot river Mandakini water. ${ }^{[12]}$ Tripathi et al.2016, Physico-chemical characteristics of surface water samples collected from river mandakini at chitrakoot region, found the temperature ranged between $28^{\circ} \mathrm{C}$ to $35.2{ }^{\circ} \mathrm{C}$.

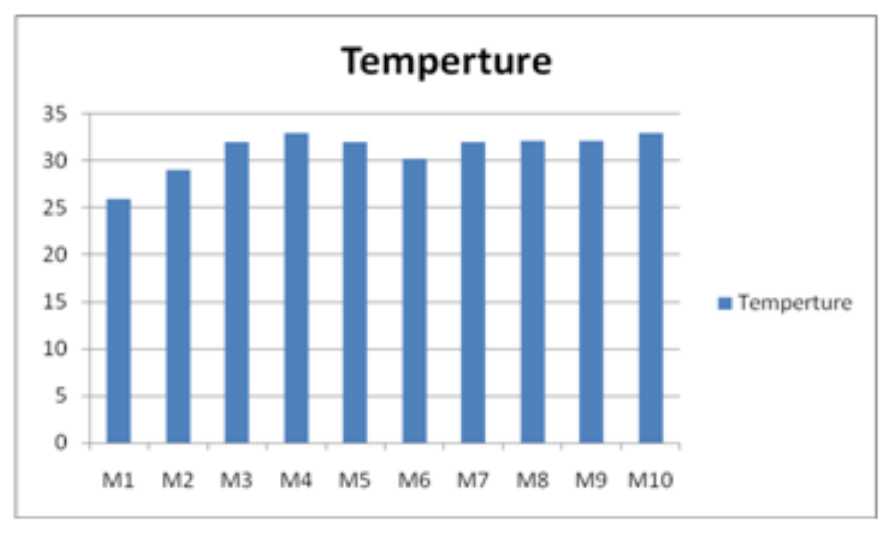

Figure1. temperature at various locations of River Mandakini

\section{2.pH}

The $\mathrm{pH}$ value of water sample are between 6.1to 7.0. All the results were below the permissible limit prescribed by WHO (1984) as $8.5 \mathrm{mg} / \mathrm{l}$. The highest $\mathrm{pH}$ was absorbed of sampling location $\mathrm{M}_{9}(7.0)$ while the lowest $\mathrm{pH}$ was detected at sampling location $\mathrm{M}_{5}(6.1) .{ }^{[1] 3}$ Tripathi et al. 2016 physicochemical Studies on ground water and surface water in and around katni city, Madhya Pradesh and observed the $\mathrm{pH}$ concentrations ranged from 6.9 to 8.1 .

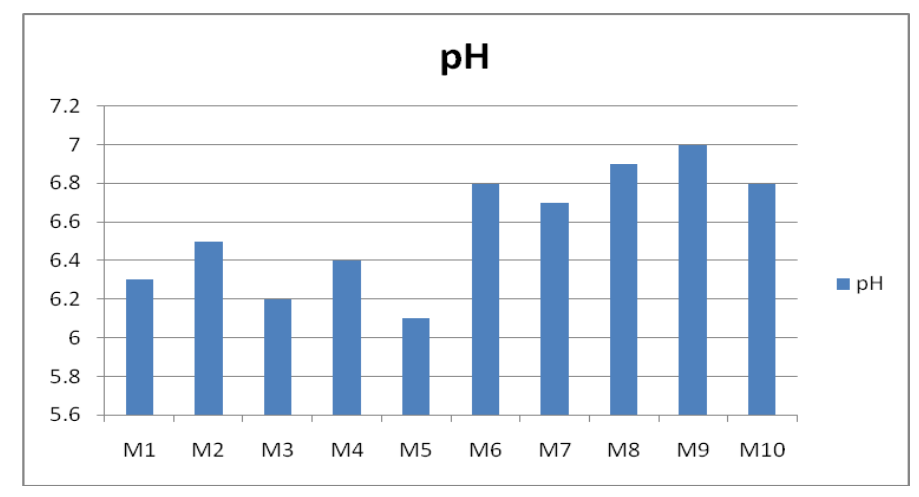

Figure2. $p H$ at various locations of River Mandakini

\subsection{Alkalinity}

Alkalinity is a measure of the concentration of such ions in water that would react to neutralize hydrogen ions. Abnormally high alkalinity imparts bitter test to water and makes it unpalatable. In present study lowest value of alkalinity was found $210 \mathrm{mg} / \mathrm{l}$ and higher value found $500 \mathrm{mg} / \mathrm{l}$. The highest Alkalinity was absorbed of sampling location $\mathrm{M}_{4}(500)$ while lowest Alkalinity was detected at sampling location $\mathrm{M}_{5}(210 \mathrm{mg} / \mathrm{l}) .{ }^{[14]} \mathrm{Kamboj}$ et al.2015, carried out quality assessment of municipal 
supplied water for drinking purpose, district Haridwar, Uttarakhand, India, have reported Alkalinity ranged between 210 to $249 \mathrm{mg} / \mathrm{l}$. Alkalinity in water comes from calcium carbonate, $\mathrm{CaCO}_{3}$, being leached from rocks and soil.

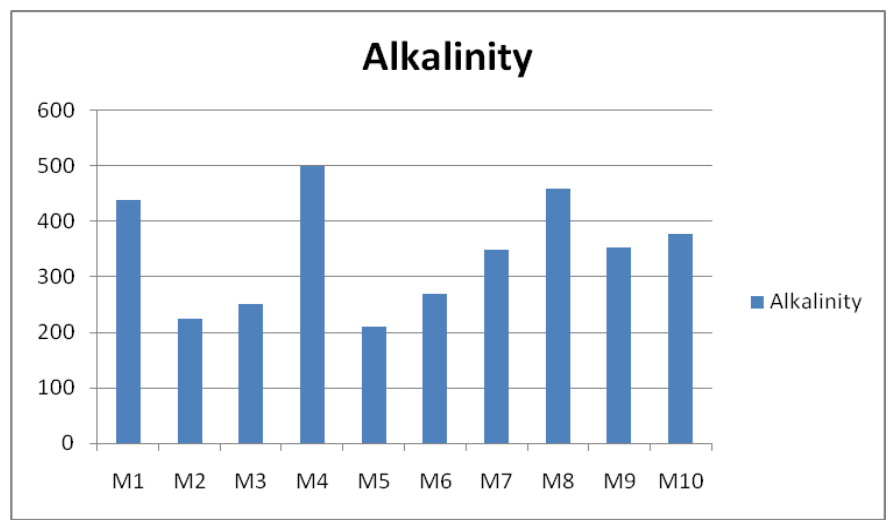

Figure3. Alkalinity at various locations of River Mandakini

\subsection{Chloride}

Chloride occurs naturally in all types of water. Chloride is soluble in water and moves freely with water through soil and rocks. Chloride salts in excess of $100 \mathrm{mg} / \mathrm{l}$ give salty taste to water. In this work highest value of chloride $555 \mathrm{mg} / \mathrm{l}$ and lowest value is $85 \mathrm{mg} / \mathrm{l} .{ }^{[15]}$ Tripathi et al.2013 studied characterization of diffuse chemical pollution in Satna District of Vindhya Region, India, Chloride concentration was analyzed and found the chloride content ranged between 5.0 to $82.0 \mathrm{mg} / \mathrm{l}$.

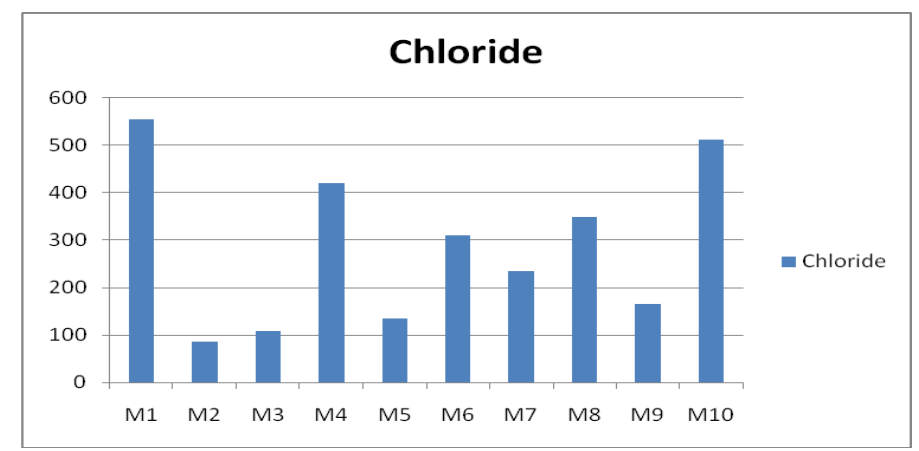

Figure4. Chloride at various locations of River Mandakini

\subsection{Total Dissolve Solid}

In natural water, total dissolved solid (TDS) are composed mainly of carbonate, bicarbonate, chloride, sulphate, phosphate, nitrate, $\mathrm{Ca}, \mathrm{Mg}, \mathrm{Na}, \mathrm{K}, \mathrm{Fe}, \mathrm{Mn}$ etc., (Esmaeili and Johal,2005). Pond water samples with a high total dissolved solids indicated more ionic concentration, which is of inferior pot ability and can induce an unfavorable physic-chemical effect in the consumers. In the present study TDS was found 118 to $548 \mathrm{mg} / \mathrm{l}$. Maxmium TDS (548 mg/l) was detected at sampling station $\mathrm{M}_{10(\mathrm{Karvi}) .}{ }^{[16]}$ Zinjad et al. 2013 carried out physic-chemical parameters of drinking water in parvara areas around parvara and TDS value was found ranged between 481-655.0 mg/l.

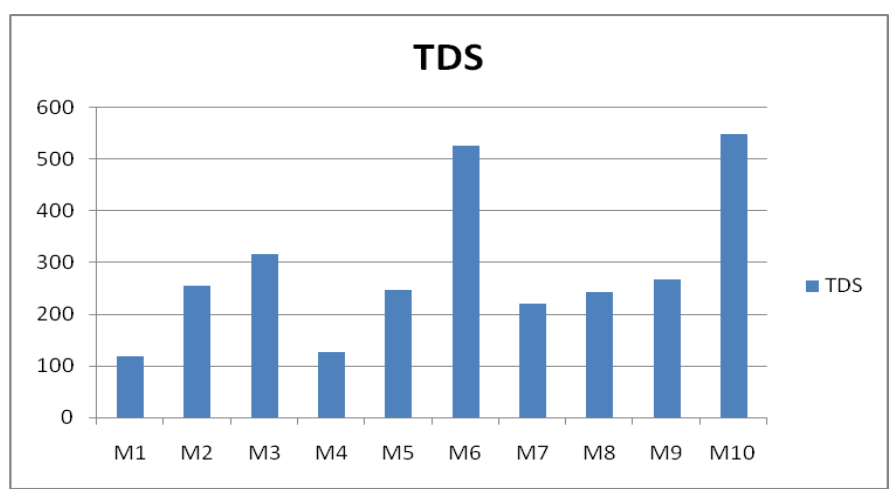

Figure5. TDS at various locations of River Mandakini 


\subsection{Total Hardness}

In present study of TH highest value found $621 \mathrm{mg} / \mathrm{l}$ and lowest value found $249 \mathrm{mg} / \mathrm{l}$. Most of stations were found higher values of hardness. ${ }^{[17]}$ Sharma et al. 2013 study in physic-chemical analysis of surface and ground water of abhanpur block in Raipur district, Chhattisgarh, studied the water hardness ranged from a 130 to $280 \mathrm{mg} / \mathrm{l}$.

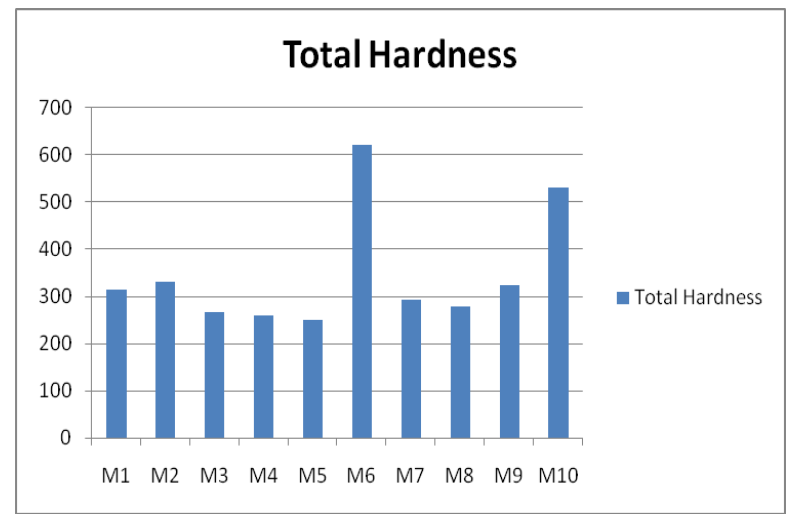

\subsection{Sulphate}

Figure6. Total Hardness at various locations of River Mandakini

Sulphate is naturally occurring anion in all kinds of natural waters. The sulphate concentration ranged from 4 to $43 \mathrm{mg} / \mathrm{l}$. The maximum concentration was detected at sampling location M8 (43) while minimum concentrations sampling location M2 $(4 \mathrm{mg} / \mathrm{l})$. All the results were below the permissible limit prescribed WHO (1984) $250 \mathrm{mg} / 1 .{ }^{[18]}$ Tripathi et al.2016, statistical assessment of surface water resources in east zone of central India and reported the sulphate concentrations ranged between 0.003 to $6.0 \mathrm{mg} / \mathrm{l}$.

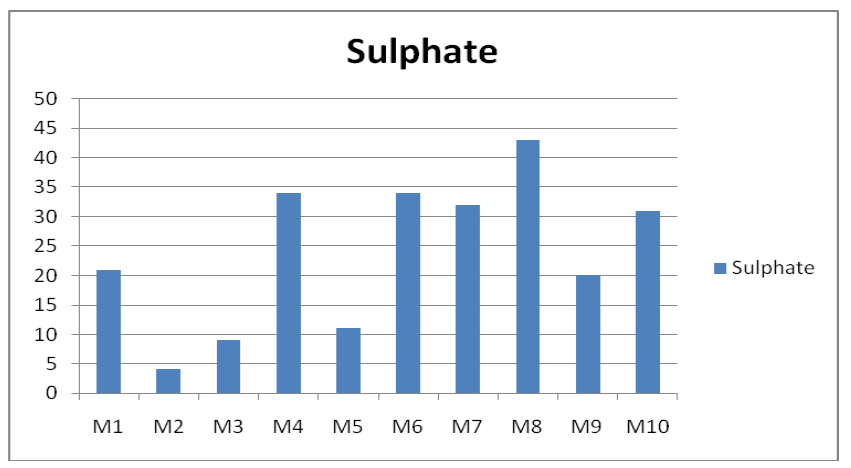

Figure7. Sulphate at various locations of River Mandakini

\subsection{Phosphate}

The permissible limit of ${ }^{[19]}$ USPHS for phosphate is $0.1 \mathrm{mg} / \mathrm{l}$. all the collected samples have phosphate concentration ranging from 0.00 to $0.009 \mathrm{mg} / \mathrm{l}$. all the water samples of phosphate concentration are under the limit of ${ }^{[20]}$ USPHS as $0.1 \mathrm{mg} / \mathrm{l} .{ }^{[21]}$ Prasanna et al. 2010, studied physicchemical properties of water collected from Dharma Estuary and analysed the phosphate content and values were found ranged between 0.04 to $1.15 \mathrm{mg} / \mathrm{l}$.

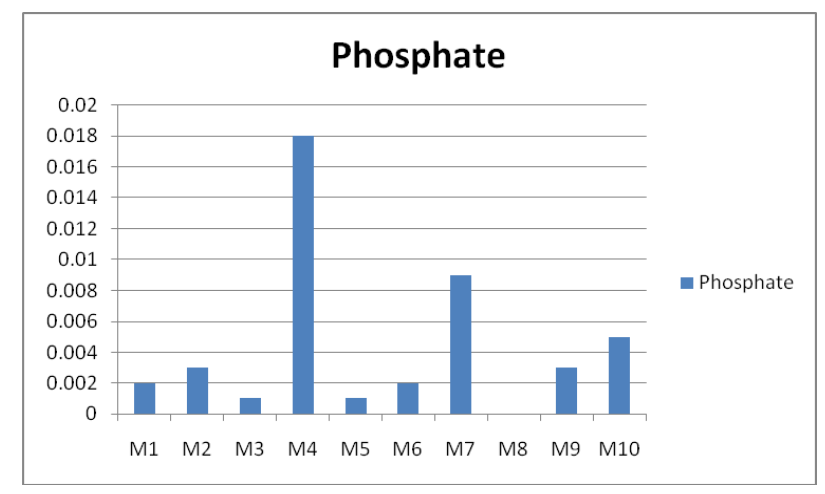

Figure8. Phosphates at various locations of River Mandakini 
Table1. The Physico-chemical Characteristics of River water from Different Locations of Chitrakoot

\begin{tabular}{|l|l|l|l|l|l|l|l|l|}
\hline Sampling station & Temperature & $\mathbf{p H}$ & TDS & Alkalinity & Chloride & Total Hardness & Sulphate & Phosphate \\
\hline $\mathbf{M}_{1}$ & 26 & 6.3 & 118 & 439 & 555 & 315 & 21 & $\mathbf{0 . 0 0 2}$ \\
\hline $\mathbf{M}_{2}$ & 29 & 6.5 & 256 & 225 & 85 & 330 & 4 & $\mathbf{0 . 0 0 3}$ \\
\hline $\mathbf{M}_{3}$ & 32 & 6.2 & 316 & 250 & 109 & 266 & 9 & $\mathbf{0 . 0 0 1}$ \\
\hline $\mathbf{M}_{4}$ & 33 & 6.4 & 126 & 500 & 420 & 260 & 34 & $\mathbf{0 . 0 1 8}$ \\
\hline $\mathbf{M}_{5}$ & 32 & 6.1 & 246 & 210 & 134 & 249 & 11 & $\mathbf{0 . 0 0 1}$ \\
\hline $\mathbf{M}_{6}$ & 30.2 & 6.8 & 527 & 270 & 310 & 621 & 34 & $\mathbf{0 . 0 0 2}$ \\
\hline $\mathbf{M}_{7}$ & 32 & 6.7 & 221 & 350 & 234 & 294 & 32 & $\mathbf{0 . 0 0 9}$ \\
\hline $\mathbf{M}_{8}$ & 32.2 & 6.9 & 243 & 460 & 350 & 278 & 43 & $\mathbf{0 . 0 0}$ \\
\hline $\mathbf{M}_{9}$ & 32.2 & 7.0 & 267 & 354 & 165 & 325 & 20 & $\mathbf{0 . 0 0 3}$ \\
\hline $\mathbf{M}_{10}$ & 33 & 6.8 & 548 & 378 & 513 & 532 & 31 & $\mathbf{0 . 0 0 5}$ \\
\hline
\end{tabular}

M1=Sfaticshila, M2=Nagaji, M3=Arogyadham, M4= Jankikund, M5=Siyaram Kuteer, M6=Ramghat, M7= Sitapur, M8=Sonepur, M9=Karvi, Sonepur Ke Medium Me, M10=Karvi

Table2. WHO Guideline for Drinking Water Quality. 1984

\begin{tabular}{|l|l|}
\hline Parameter & Standard value \\
\hline $\mathrm{pH}$ & $6.5-8.5$ \\
\hline Total Hardness & $300 \mathrm{mg} / \mathrm{l}$ \\
\hline TDS & $200-250 \mathrm{mg} / \mathrm{l}$ \\
\hline Alkalinity & 600 \\
\hline Chloride & $250 \mathrm{mg} / \mathrm{l}$ \\
\hline Sulphate & $200 \mathrm{mg} / \mathrm{l}$ \\
\hline Phosphate & $0.1 \mathrm{mg} / \mathrm{l}$ \\
\hline
\end{tabular}

\section{CONCLUSION}

In the present study analyzed physic-chemical properties of River Mandakini from the Chosen selected sampling locations. Samples were collected determined the following parameters Temperature, pH, Alkalinity, TDS, Total Hardness, Chloride, Sulphate and Phosphate. The Temperature values were found $26^{\circ} \mathrm{C}$ to $33^{\circ} \mathrm{C}$.pH6.1 to 7.0 , Alkalinity 210to $500 \mathrm{mg} / \mathrm{l}$., Chloride 5.0 to $82 \mathrm{mg} / \mathrm{l}$, TDS 118 to $548 \mathrm{mg} / \mathrm{l}$, Total Hardness 249 to $621 \mathrm{mg} / \mathrm{l}$, Sulphate 4.0 to $43 \mathrm{mg} / \mathrm{l}$. and phosphate 0.00 to $0.009 \mathrm{mg} / \mathrm{l}$. Same samples of Alkalinity, Total Dissolve Solid and Total Hardness were found more than the permissible limit prescribed by $\mathrm{WHO}(1984)$.Temperature, $\mathrm{pH}$, Chloride,

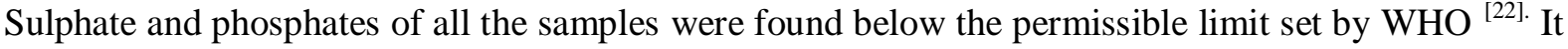
is concluded that the water of river is not highly polluted but there is an indicating of increasing pollutant due to anthropogenic activities. Proper monitoring is needed to avoid anthropogenic contamination.

\section{ACKNOWLEDGEMENTS}

We express our sincere thanks to the Head, Department of Chemistry, for successful completion of this research work

\section{REFERENCES}

[1] S.L.Dwivedi and V. Pathak, Apreliminary Assignment of Water Quality Index to Mandakini River, Chitrakoot. Indian Journal Environmental Protection, 2007, 27 (11), 53-58.

[2] A.K.Rai, Biswajit Paul and Gurdeep Singh, Effect of Waste Disposal on water Quality of River Harmu in Ranchi city, Jharkhand, IJEP, 2011,31 (9), 758-763.

[3] B.S. Sreenivas, Impact of Industrial Effluents and Sewage on the water Quality of River Godavari at Bhadrachalam Temple Town in South India, IJEP, 2006, 12 (3), 543-552.

[4] Y. Ramani Bai and T.F. Abbs Fen Reji, Analytical study on Quality of a River for Drinking and Irrigation purpose, IJEP, 2014, 34(9), 775-782.

[5] B.N. Singh and S. Rai, Physico-chemical studies of Ganga River at Varanasi, J. Environ.Pollut.. 1999, 6, 43-46.

[6] M. P.Lilly Florence, Ground Water Quality Assessment of Gangavalli Taluk, Salem District, Tamil Nadu, India. Multivariate Statistical Techniques Iracst Engineering Science and Technology: an International Journal, 2013,3 (1), 2250-3498.

[7] ICMR, 1975.Manual of Standard of Quality for Drinking water, ICMR Delhi $2^{\text {nd }}$ ed.1975.

[8] NEERI, 1988, Manual on Water and Waste Water Analysis, Nagpur 1998.

[9] WHO Guideline for Drinking Water Monograph series No.42, 1999 
[10] Standard Method of water and weste water Analysis, APHA, AWWA, USA, 2005.

[11] Sadhana Chaurasia and Raj Karan, Assessment of Water Quality Index and Trophic State of River Mandakini, India, International Journal of Plant, Animal and Environmental Science, 2014, 4 (343)

[12] Indra Prasad Tripathi, Arvind Prasad Dwivedi and Denesh Kumar, Physico-chemical Characteristics of Surface Water Samples Collected from River Mandakini at Chitrakoot Region, International Journal of Scientific Engineering and Technology, 2016,5(1), 76-80.

[13] Indra Prasad Tripathi, Arvind Dwivedi and Rinku Sahu, Physico-chemical Studies on Ground Water and Surface Water in and Around Katni City, Madhya Pradesh, International Journal of Information Research and Review, 2016, 3 (1), 1722-1729.

[14] Nitin Kamboj, Anup Kumar Chaubey, Sandeep Kumar and Chander Kant Parasher, Quality Assessment of Municipal Supplied water for Drinking Purpose, District Haridwar, Uttarakhand, India, Journal of Global Bio Science, 2015,4(5), 2375-2379.

[15] Indra Prasad Tripathi, M. Suresh Kumar and Arvind Prasad Dwivedi, Characterization of Diffuse Chemical Pollution in Satna District of Vindhya Region, India. International Research Journal of Environment Sciences, 2013, 2 (11), 46-60.

[16] D.G. Zindal, Study of Physico- chemical Parameters of Drinking Area around Parvavara River, Journal of applicable Chemistry, 2005, 2 (30 545-548.

[17] Pramisha Sharma Amit Dubey and S.K. Chatterjee, Physico-chemical Analysis of surface and ground water of Abhanpur Block in Raipur District, Chhattisgarh, IJTEE, 2013, 2.

[18] Indra Prasad Tripathi and arvind Prasad Dwivedi, Statistical Assessment of Surface Water Resources in East Zone of Central India, International Journal of Science Technology \& Engineering, 2016, 2 (9) 6877.

[19] H.R. Esmarili and M.S. Johal, Study of physico-chemical parameters of water of Gobindnagar Reservoir, India. National Seminar on New trends in fisheries development in India. Chandigarh, 2005

[20] S. Santhi, D. Kalaivani, A. Mahalakshmi and S. Amala, Physico-chemical Studies on Water Quality in Thirukattupalli Near Thanjavur, IJEP, 2015,34(9): 765-768

[21] Muddeli Bipara Prasanna, Physico-chemical properties of Water Collected from Dharma Estuary and Analyzed the Phosphate, IJEP, 2010

[22] WHO, Guideline for Drinking Water Quality, Vol 2. Geneva (1984)

Citation: Dr. A. Prasad Dwivedi, "Study of Physico- chemical Characteristics of Water in River Mandakini", International Journal of Advanced Research in Chemical Science (IJARCS), vol. 4, no. 9, pp. 1-6, 2017. http://dx.doi.org/10.20431/2349-0403.0409001

Copyright: (C) 2017 Authors. This is an open-access article distributed under the terms of the Creative Commons Attribution License, which permits unrestricted use, distribution, and reproduction in any medium, provided the original author and source are credited. 